\title{
Radiological and radio-therapeutic nuances in skull base tumors
}

Citation for published version (APA):

Alahmari, M. A. (2021). Radiological and radio-therapeutic nuances in skull base tumors: $A$ focus on efficacy and safety in chordoma and vestibular schwannoma. [Doctoral Thesis, Maastricht University]. Maastricht University. https://doi.org/10.26481/dis.20210915ma

Document status and date:

Published: 01/01/2021

DOI:

10.26481/dis.20210915ma

Document Version:

Publisher's PDF, also known as Version of record

\section{Please check the document version of this publication:}

- A submitted manuscript is the version of the article upon submission and before peer-review. There can be important differences between the submitted version and the official published version of record.

People interested in the research are advised to contact the author for the final version of the publication, or visit the DOI to the publisher's website.

- The final author version and the galley proof are versions of the publication after peer review.

- The final published version features the final layout of the paper including the volume, issue and page numbers.

Link to publication

\footnotetext{
General rights rights.

- You may freely distribute the URL identifying the publication in the public portal. please follow below link for the End User Agreement:

www.umlib.nl/taverne-license

Take down policy

If you believe that this document breaches copyright please contact us at:

repository@maastrichtuniversity.nl

providing details and we will investigate your claim.
}

Copyright and moral rights for the publications made accessible in the public portal are retained by the authors and/or other copyright owners and it is a condition of accessing publications that users recognise and abide by the legal requirements associated with these

- Users may download and print one copy of any publication from the public portal for the purpose of private study or research.

- You may not further distribute the material or use it for any profit-making activity or commercial gain

If the publication is distributed under the terms of Article $25 \mathrm{fa}$ of the Dutch Copyright Act, indicated by the "Taverne" license above, 


\section{Thesis Summary}

Chordoma and vestibular schwannoma (VS) are both tumors that appear in the posterior fossa of the skull base; however, they are different in nature. Skull base chordoma is malignant, very rare (affects one in a million), originates from the remnants of the embryonic notochord, and infiltrates in all types of neighboring tissues without predilection. By contrast, VS is benign, representing $8-10 \%$ of all intracranial tumors. It originates from the Schwann cells of the vestibular cranial nerve, and its boundaries are easy to identify. These different natures highlight the gravity of the situation faced by the tumor management team during treatment, with skull base chordoma being more challenging. As of the critical location of both types of tumors, an increase in size means more involvement of cranial nerves and major vessels and may cause severe symptoms such as hydrocephalus, ventricular obstruction, or symptomatic mass effects resulting from brain stem compression. Thus, a surgical intervention is the norm for both types of tumors when they are large in size. Due to the high survivability of chordoma cells, a high radiation dose of $\sim 74 \mathrm{~Gy}$ (preferably proton therapy (PT)) is normally given to control the post-surgery growth of tumor cells. Concerning VS, the vast majority of treatment options nowadays have shifted from saving lives to preserving functions and minimizing morbidities, in which Gamma Knife (GK) radiosurgery has played an important role as either a primary treatment or an adjuvant. With the aim of providing patients with the safest and most reliable care, this thesis evaluated the radiological and radiotherapeutic nuances in patients with skull base chordoma and large VS after applying the recommended types of radiation therapy post-surgery: PT and GK, respectively. The scope of the thesis includes new knowledge addressing treatment-related issues in the field of radiology and physics.

Based on certain inclusion and exclusion criteria, Chapter 2 systematically reviewed all articles published between 1980 and 2018 that reported on the use of PT after surgery concerning skull base chordoma patients. Thus, a better insight was gained into the efficacy of PT with regard to growth control and radiation-induced effects. Based on the review, we found that in $25 \%$ of cases, skull base chordoma is expected to recur within three years, even after a high dose of PT. To attain a deeper understanding of recurrence after PT, in Chapter 3, we critically evaluated seven cases of recurrent skull base chordoma after surgery and PT, aiming to find a pattern of recurrence. The correlation between the location of the recurrence and both the surgical trajectory and PT corridors was taken into account. Almost all the loco-regional recurrences could be related to prior surgical cavities, outside the therapeutic radiation dose ( $>60 \mathrm{GyE}$ ). Our theory is that these recurrences are due to microscopic tumor spills during surgery that did not receive a curative radiation dose. The most serious radiation-induced side 
effect was brain necrosis. Brain necrosis is the most common form of late toxicity after PT, as described in Chapter 2. Beyond its effect on the patient's quality of life, follow-up imaging showed that radiation necrosis is difficult to distinguish from tumor progression and anatomical distortion after surgery. Skull base chordoma remains a challenge to manage; therefore, a multidisciplinary joint effort is necessary in all treatment stages for every single patient.

Chapter 4 provided an update on the pathophysiology and imaging characteristics and discussed the latest insights in the management of VS, including both its sporadic types and NF2. This chapter also highlighted the growing interest in the combined approach (partial resection followed by a GK dose) for patients with large VS. As this approach is yet to be the international standard, in Chapter 5, a group of 25 patients with large VS who had undergone combined treatment were retrospectively analyzed. Surgeries reduced the median tumor volume from $9.35 \mathrm{~cm}^{3}$ to $3.27 \mathrm{~cm}^{3}$. Following surgeries, all patients maintained their preexisting good FN functions (H-B Grade 1), except for one, who had a temporary H-B Grade 3 (resolved after 4 weeks). To control the VS residues after surgery, all patients were prescribed a dose of GK radiosurgery (mean $=12.9 \mathrm{~Gy}$ ). In the last follow-up time (median 37 months), all patients enjoyed H-B Grade 1 of FN functions (100\% success rate). The achieved control rate at the last follow-up time was $88 \%$. No association was found between any of the demographic or morphologic features and the tumor response after completing the treatment. No patient developed any surgical-related complications or late radiation-induced toxicities. The treatment of upfront planning for a partial resection followed by GK radiosurgery (12-13 Gy) for patients with large VS is an efficient and safe choice.

In general, the surgical success rate is highly dependent on the surgeon's experience and on the precision of the tools or equipment used. Prior to VS surgery, MRI has an essential role in identifying the $\mathrm{FN}$ condition using a diffusion-weighted imaging sequence (DWI). Chapter 6 of this thesis focused on implementing one of the DWI sequence parameters described in previous literature (by Song et al.) on a healthy volunteer and then comparing it with another four modified DWI sequences. Chapter 6 showed that a small alteration in one parameter of those used by Song et al. (repetition time (TR)) resulted in a successful depiction of the FN bilaterally, separate from the vestibulocochlear nerve. An important aspect of the optimized sequence is that it follows the widely used DWI method (conventional DWI), which is easy and quick to implement in surgical planning. The proposed sequence will be further evaluated in future using larger sample in a clinical setting.

Finally, this thesis has concluded with a chapter addressing one of the knowledge gaps in radiation therapy planning concerning uncertainties in dose distribution at low dose regions. The study in Chapter $\mathbf{7}$ was conducted to quantify differences between two 
dose calculation algorithms (AAA and Acuros) using computed tomography (CT) scans of 10 patients with neuro metastases. After recalculating the 3D dose distributions using both algorithms, the mean and maximum doses for the relevant organs at risk (OARs) were extracted using the dose-volume histograms (DVHs). The results showed that the agreement level between the two algorithms is high, and almost all the differences in each OAR are located well within the default tolerance limits, suggesting that $A A A$ and Acuros $X B$ could be used interchangeably in patients with neurological tumors for low-dose regions. However, Acuros XB holds superiority over AAA in terms of computation speed. This chapter has contributed to the main aim of this thesis by ensuring the radiation safety of patients with neurological tumors. 